\title{
Photo-oxidation of PAHs with calcium peroxide as a source of the hydroxyl radicals
}

\author{
Jolanta Kozak $^{1, *}$, Maria Włodarczyk-Makuła ${ }^{2}$ \\ ${ }^{1}$ Czestochowa University of Technology, Department of Chemistry Water and Wastewater \\ Technology, Dąbrowskiego st 69, 42-200 Czestochowa, Poland \\ ${ }^{2}$ Czestochowa University of Technology, Department of Chemistry Water and Wastewater \\ Technology, Dąbrowskiego st 69, 42-200 Czestochowa, Poland
}

\begin{abstract}
The efficiency of the removal of selected PAHs from the pretreated coking wastewater with usage of $\mathrm{CaO}_{2}$, Fenton reagent $\left(\mathrm{FeSO}_{4}\right)$ and UV rays are presented in this article. The investigations were carried out using coking wastewater originating from biological, industrial wastewater treatment plant. At the beginning of the experiment, the calcium peroxide $\left(\mathrm{CaO}_{2}\right)$ powder as a source of hydroxyl radicals $(\mathrm{OH} \cdot)$ and Fenton reagent were added to the samples of wastewater. Then, the samples were exposed to UV rays for $360 \mathrm{~s}$. The process was carried out at $\mathrm{pH}$ 3.5-3.8. After photo-oxidation process a decrease in the PAHs concentration was observed. The removal efficiency of selected hydrocarbons was in the ranged of $89-98 \%$. The effectiveness of PAHs degradation was directly proportional to the calcium peroxide dose.
\end{abstract}

\section{Introduction}

PAHs, along with other environmental pollutants, such as: pesticides, endocrine disruptor contaminants (EDCs), PPCPs- Pharmaceuticals and Personal Care Products, retardants and others belongs to a group of compounds known as persistent environmental pollutants. These compounds are characterized by high toxicity, persistence and bioaccumulation potential [1-4] Sources of PAHs are mainly anthropogenic activities, especially during incomplete combustion of organic matter in various industries and other human activities like tobacco smoking, burning coal, petrol, gas and other fossil fuels [5-7] The main sources of pollution aquatic environment are untreated industrial wastewater, in particularly coking wastewater (coking wastewater, petrochemical). The above mentioned wastewater is the most polluted with PAHs, thus they have been choosing for investigations [8-9] The presence of PAHs in pretreated coking wastewater is confirmed by literature sources [10-11] In Poland there are not available regulations of the permissible PAHs concentration in the treated wastewater discharging to the receiver. It is only pointed out that carcinogenic compounds should be monitored in the surface water.

Advanced Oxidation Processes (AOPs) have been increasingly applied in the treatment of industrial wastewater. In AOPs methods the formation of a hydroxyl radical is formed.

*Corresponding author: j.kozak@is.pcz.pl ;mwm@is.pcz.czest.pl 
Hydroxyl radicals are able to decompose organic compounds into $\mathrm{CO}_{2}$ and $\mathrm{H}_{2} \mathrm{O}$. In AOPs processes are used: $\mathrm{H}_{2} \mathrm{O}_{2}$, potassium manganese, ozone, UV radiation, ultrasound, or methods involving the combined action of a chemical reagent with irradiation or ultrasound [12-15] The literary investigations indicate that simultaneous usage of several reagents results in the most effective degradation of pollutants. The former studies have suggested that $\mathrm{CaO}_{2}$ is more efficient source of hydroxyl radicals $(\mathrm{OH} \cdot)$ than the $\mathrm{H}_{2} \mathrm{O}_{2}$ [16-17] Among other reagents able to release $\mathrm{OH}$ (such as $\mathrm{Na}_{2} \mathrm{CO}_{3}, \mathrm{MgO}_{2}$ ) $\mathrm{CaO}_{2}$ has been selected for these studies due to its relatively low cost. The release of $\mathrm{OH}$. from $\mathrm{CaO}_{2}$ is gradual, and appears only under acidic, aquatic environments [18] The process of dissolving $\mathrm{CaO}_{2}$ to $\mathrm{H}_{2} \mathrm{O}_{2}$ and $\mathrm{Ca}(\mathrm{OH})_{2}$ takes place according to the reaction (1) [14].

$$
\mathrm{CaO}_{2}+2 \mathrm{H}_{2} \mathrm{O} \rightarrow \mathrm{H}_{2} \mathrm{O}_{2}+\mathrm{Ca}(\mathrm{OH})_{2}
$$

Therefore, it seems reasonable to carry out the experiments using the afore mentioned reagent.

The main objective of the study is to determine the effectiveness of PAHs removal with $\mathrm{CaO}_{2}$ as an alternative source of hydroxyl radicals in the photo-Fenton process. The focus of the study was on PAHs analysis with 4-6 benzene rings selected from the US EPA list due to their high carcinogenicity [19] Table. 1. Characteristics of selected PAHs.

Table. 1. Characteristics of study PAHs [19]

\begin{tabular}{|l|c|c|c|c|}
\hline \multicolumn{1}{|c|}{ Name } & $\begin{array}{c}\text { Chemical } \\
\text { formula }\end{array}$ & $\begin{array}{c}\text { Molar mass } \\
\text { [g/mol] }\end{array}$ & $\begin{array}{c}\text { Numbers of } \\
\text { benzene rings }\end{array}$ & Carcinogenicity index \\
\hline Pyrene & $\mathrm{C}_{16} \mathrm{H}_{10}$ & 202,25 & 4 & $\begin{array}{c}\text { Not classifiable for } \\
\text { human }\end{array}$ \\
\hline Benzo(k)fluoranthene & $\mathrm{C}_{20} \mathrm{H}_{12}$ & 252,32 & 4 & 0,1 \\
\hline Benzo(b)fluoranthene & $\mathrm{C}_{20} \mathrm{H}_{12}$ & 252,32 & 4 & 0,1 \\
\hline Benzo(a)anthracene & $\mathrm{C}_{18} \mathrm{H}_{12}$ & 228.29 & 4 & 0,1 \\
\hline Chrysene & $\mathrm{C}_{18} \mathrm{H}_{12}$ & 228,29 & 4 & 0,01 \\
\hline (Indeno(1,2,3-cd)pyrene & $\mathrm{C}_{22} \mathrm{H}_{12}$ & 276,34 & 5 & 0,1 \\
\hline Dibenzo(a,h)anthracene & $\mathrm{C}_{22} \mathrm{H}_{14}$ & 278,35 & 5 & 5 \\
\hline Benzo(a)pyrene & $\mathrm{C}_{20} \mathrm{H}_{12}$ & 252,31 & 5 & 1 \\
\hline Benzo(g,h,i)perylene & $\mathrm{C}_{22} \mathrm{H}_{12}$ & 276,33 & 6 & 0,01 \\
\hline
\end{tabular}

\section{Experimental procedure}

\subsection{Materials}

In the study coking wastewater from the industrial wastewater treatment plants was used. Wastewater was biologically treated with an activated sludge methods. In the coking wastewater organic compounds (COD) and PAHs were determined.

\subsection{Experimental procedure}


The studies were carried out using pretreated coking wastewater. In the first step was characterized COD according to the US shortcut method. Samples of wastewater were taken as temporary, then 9 PAHs, listed by US Environmental Protection Agency (EPA) were determined. Hydrocarbons containing 4-6 benzene rings are the most carcinogenic. At the beginning of the experiment $\mathrm{CaO}_{2}$ was added to the wastewater samples in the following amounts: $1 \mathrm{~g} ; 2 \mathrm{~g} ; 3 \mathrm{~g}$ per/L respectively. Samples were acidified at $\mathrm{pH}$ 3,53,8.Samples were acidified at $\mathrm{pH} 3,5-3,8$. Then Fenton reagent was added to the samples and samples were exposed to UV rays for $360 \mathrm{~s}$ in a plastic cuvette (the thickness of the exposed layer was equal to $2 \mathrm{~mm}$ ). Then, qualitative and quantitative analysis of PAH and COD was carried out.

\subsection{PAHs analysis}

PAHs analysis included extraction organic phase from coking wastewater. Cyclohexane and dichloromethane were added to the wastewater $(5: 1 \mathrm{v} / \mathrm{v})$. The mixture was shaken for 60 minutes maintaining constant amplitude. Extracts were separated from the wastewater sample on the laboratory separator. The extracts were purified on silica gel column (densification of the mixture was carried out with a mixture of dichloromethane and cyclohexane (v/v 1:5) three times). The obtaining extract was concentrated to the volume of $2 \mathrm{~mL}$ under a nitrogen stream. The final step was the quantitative and qualitative determination of 16 PAHs compounds using a GC-MS gas chromatography. The assays were carried out using a GC-MS. The temperature program was $40^{\circ} \mathrm{C} / \mathrm{min}$, heating 5 to $120^{\circ} \mathrm{C}$, and the final temperature was $280^{\circ} \mathrm{C}$ for 60 minutes.

\section{Results}

Preliminary investigations showed that the COD concentration was equal $558 \mathrm{mg} \mathrm{O}_{2} / \mathrm{L}$ in initial wastewater sample. Addition of reagents and applications of UV light resulted in the removal of COD by $30-35 \%$. The total concentration of the analyzed hydrocarbons was $5603 \mu \mathrm{g} / \mathrm{L}$ in pretreated coking wastewater. After the oxidation process total concentration of the analyzed hydrocarbons was $203 \mu \mathrm{g} / \mathrm{L}$ (after adding $3 \mathrm{~g} / \mathrm{L} \mathrm{CaO}_{2}$ ). Degree of removal was $97 \%$. Figure 1 presented decrease in concentration of pyrene depending on doses of calcium peroxide.

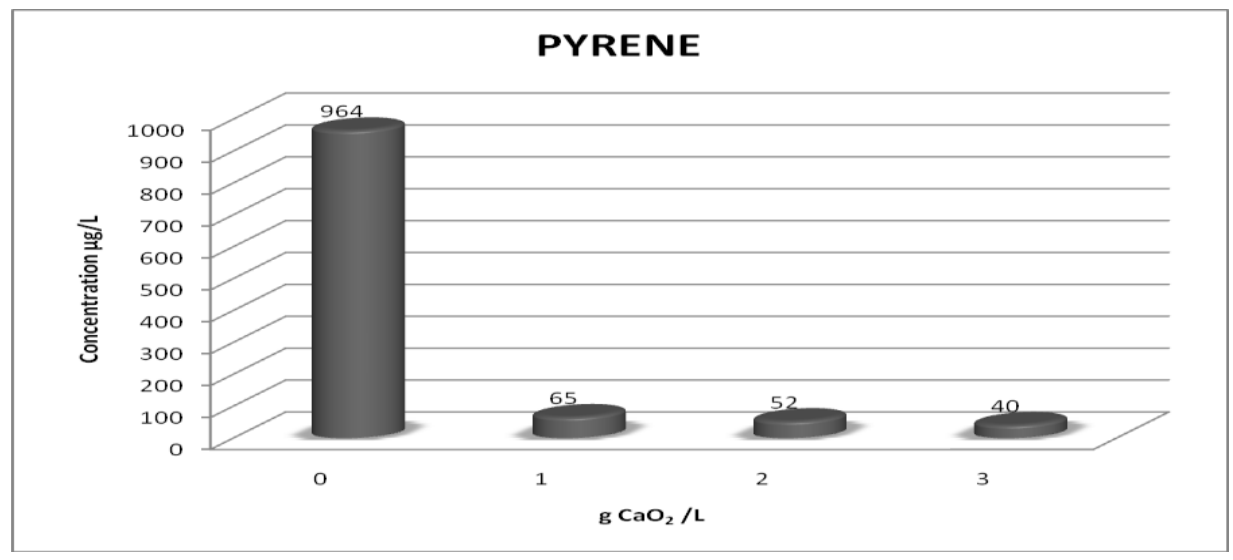

Fig. 1. Changes in the concentration of pyrene depending on dose of $\mathrm{CaO}_{2}$ added to samples. 
The highest decrease of pyrene concentration was observed for dose $\mathrm{CaO}_{2} 3 \mathrm{~g} / \mathrm{L}$. In this case efficiency of removal was $96 \%$. The degree of removal of pyrene increased gradually as the dose increased.

The highest decrease of concentration was observed for benzo(b)fluoranthene (98\%) and for its isomer benzo(k)fluoranthene( $98 \%$ ) after adding $3 \mathrm{~g} / \mathrm{L} \mathrm{CaO}_{2}$.

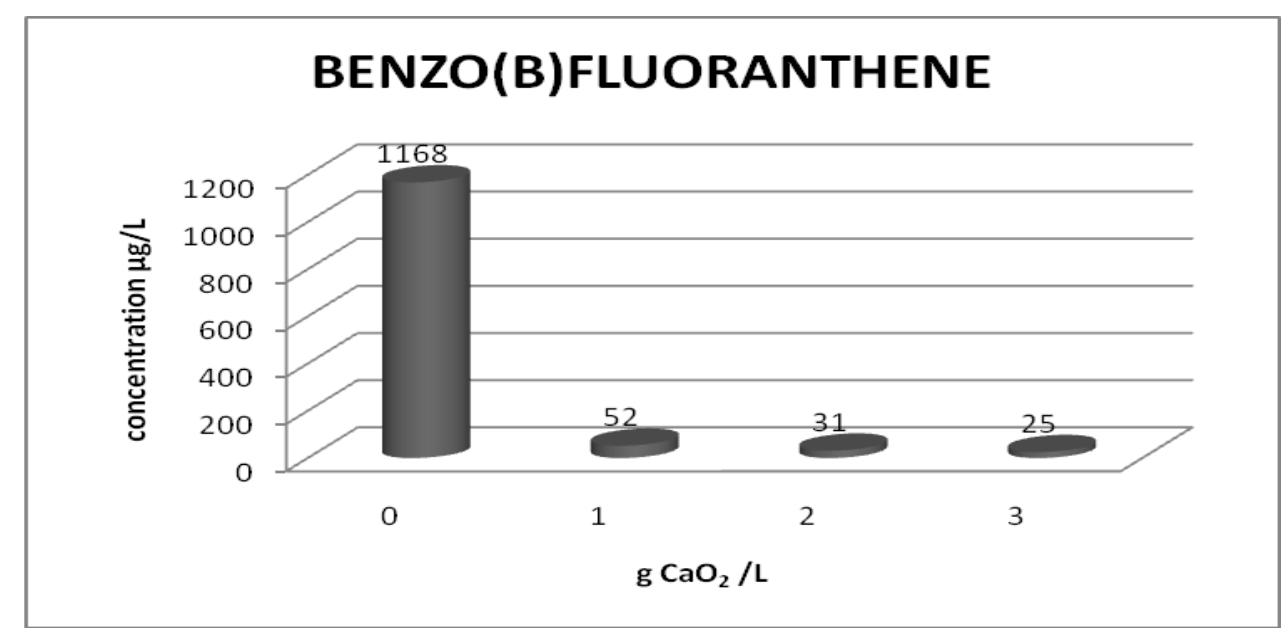

Fig. 2. Changes in the concentration of benzo(b)fluoranthene depending on dose of $\mathrm{CaO}_{2}$ added to samples.

\section{BENZO(K)FLUORANTHENE}

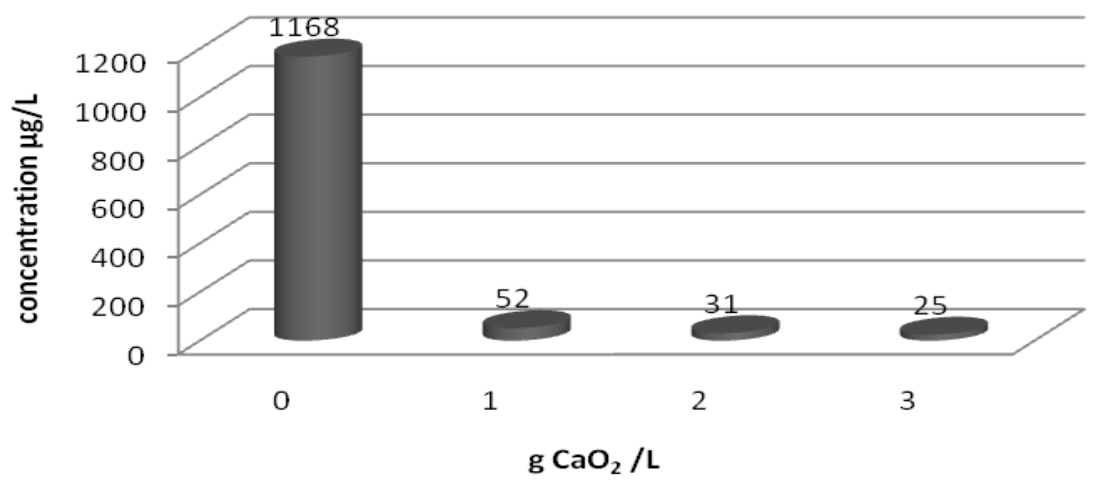

Fig. 3. Changes in the concentration of benzo(k)fluoranthene depending on dose of $\mathrm{CaO}_{2}$ added to samples.

Concentration of benzo(b)fluoranthene and its isomer gradually decreased with the increase of oxidizer dosage ( Figure 2; Figure 3).

For benzo(a)anthracene and chrysene, the situation was similar. Also after adding $3 \mathrm{~g} / \mathrm{L}$ removal efficiency was greatest and was $93 \%$ and $97 \%$. (Figure 4;Figure 5). Total concentration of hydrocarbons with 4 benzene rings was $4593 \mu \mathrm{g} / \mathrm{L}$ in pretreated coking wastewater. After oxidation process for dose $3 \mathrm{~g} / \mathrm{L} \mathrm{CaO}$ total concentration was $157 \mu \mathrm{g} / \mathrm{L}$. Degree of removal was $96 \%$ 


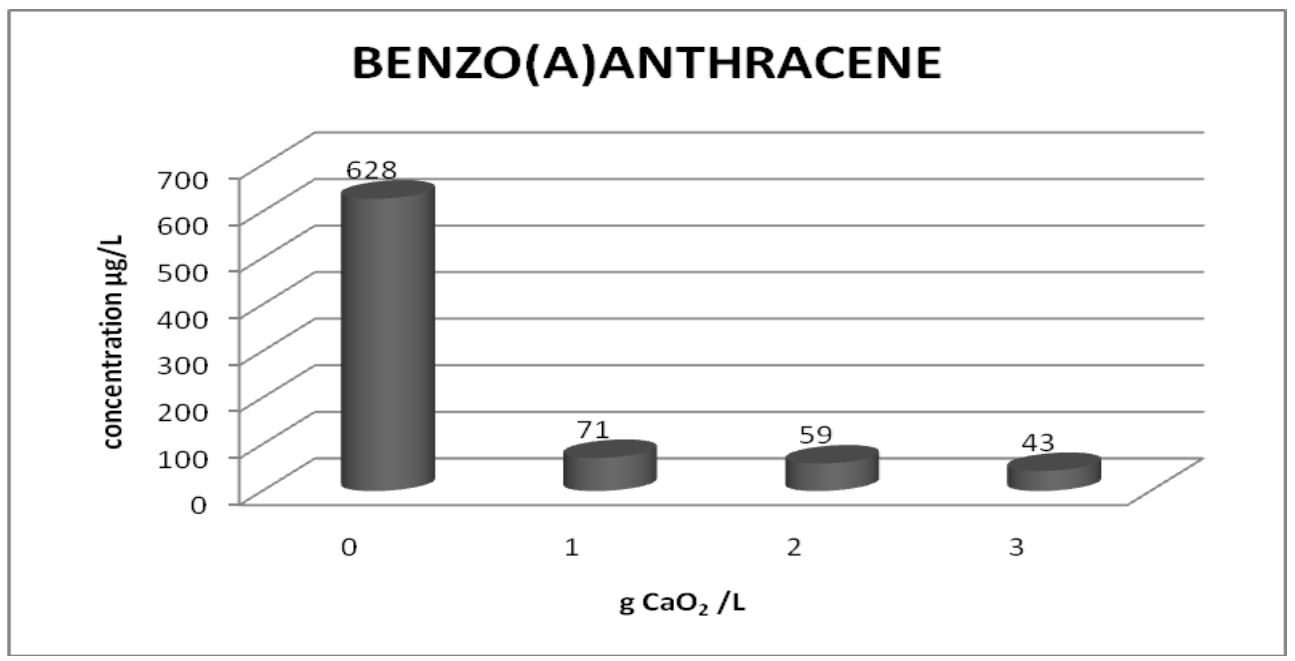

Fig.4. Changes in the concentration of benzo(a)anthracene depending on dose of $\mathrm{CaO}_{2}$ added to sample.

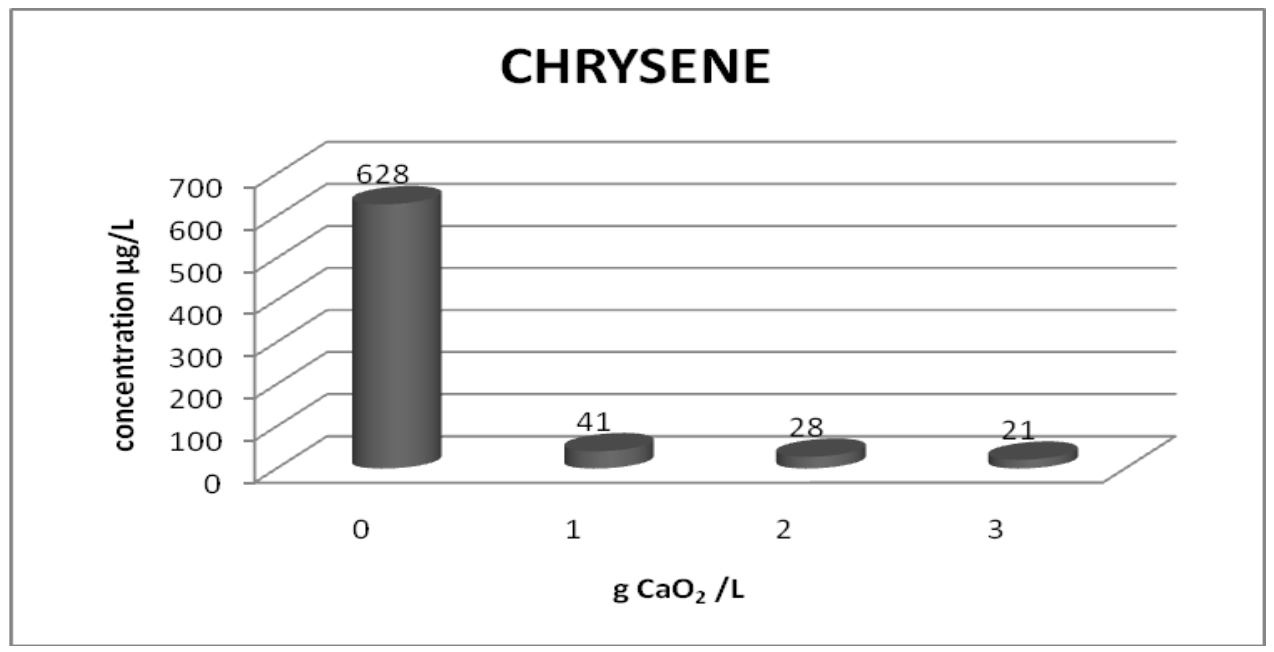

Fig. 5. Changes in the concentration of chrysene depending on dose of $\mathrm{CaO}_{2}$ added to sample.

Figure. 6 shows the changes in the concentration of benzo(a)pyrene depending on the $\mathrm{CaO}_{2}$ dose. Benzo(a)pyrene has 5 benzene rings. Total concentration of hydrocarbons with 5 benzene rings was $1716 \mu \mathrm{g} / \mathrm{L}$ in pretreated coking wastewater. The highest decrease in the concentration of benzo(a)pyrene was for the dose of $3 \mathrm{~g} / \mathrm{L} \mathrm{CaO}$. The efficiency in the removal of benzo(a)pyrene was equal to $98 \%$

The highest decrease in the concentration of indeno(1,2,3-cd)pyrene was for the dose of 3 g/L. $\mathrm{CaO}_{2}$. Degree of removal was $98 \%$ (Figure 7)

The highest decrease in the concentration of dibenzo(a,h)anthracene was for the dose of 3 $\mathrm{g} / \mathrm{L} \mathrm{CaO}_{2}$. The efficiency of the removal was equal to $96 \%$ After oxidaton process total concentration of hydrocarbons with 5 benzen rings was $38 \mu \mathrm{g} / \mathrm{L}$. For hydrocarbons with 5 benzene ring also the highest decrease in the concentration was for the dose of $3 \mathrm{~g} / \mathrm{L}$ $\mathrm{CaO}_{2}$. Removal efficiency form hydrocarbons with 5 benzene rings was $98 \%$ (Figure 8). 


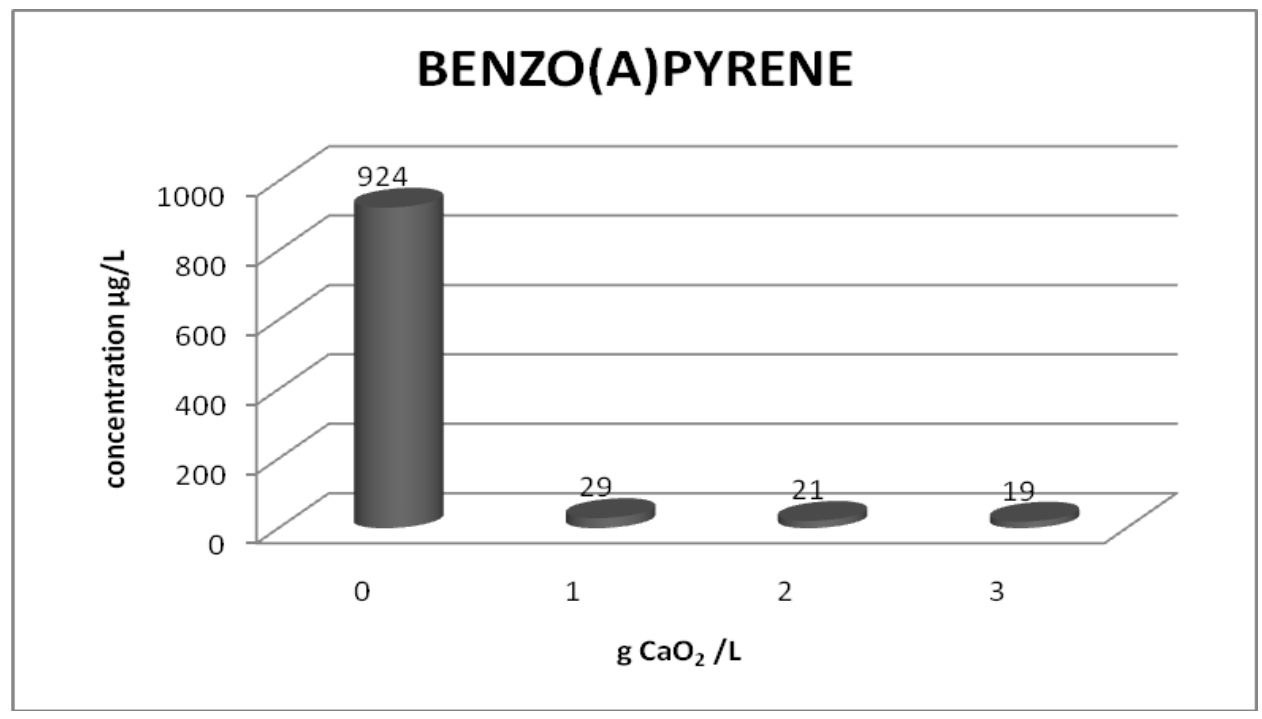

Fig. 6. Changes in the concentration of benzo(a)pyrene depending on dose of $\mathrm{CaO}_{2}$ added to sample.

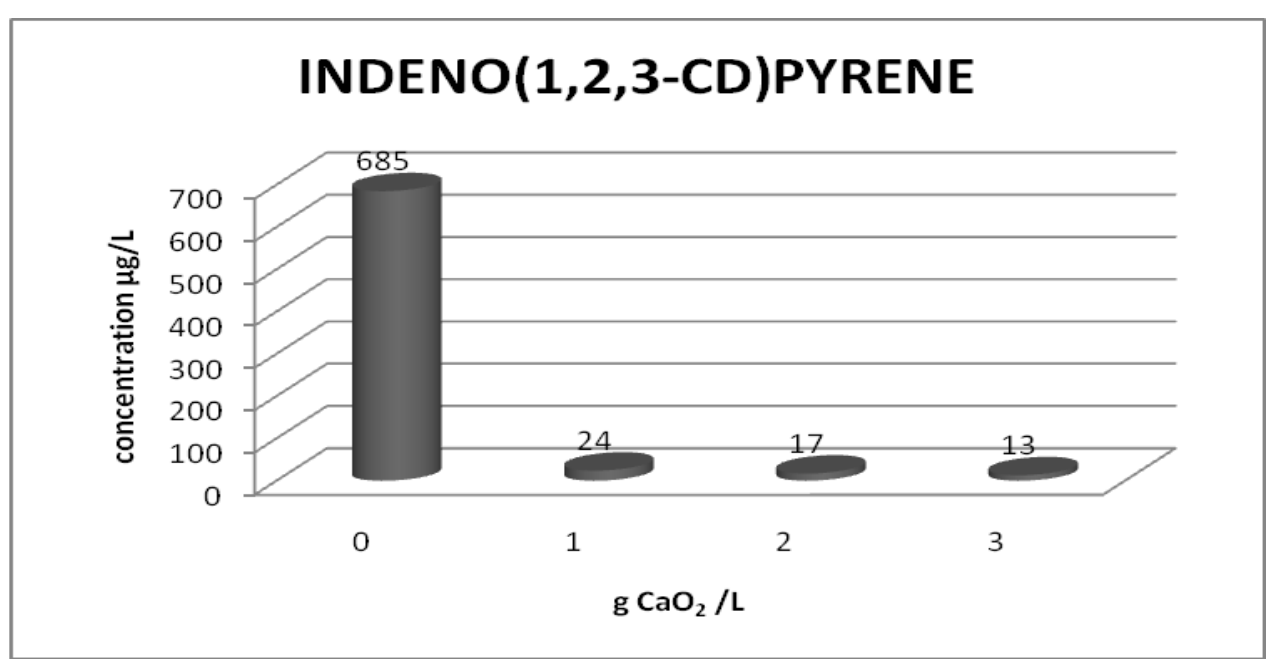

Fig. 7. Changes in the concentration of indeno(1,2,3-cd)pyrene depending on dose of $\mathrm{CaO}_{2}$ added to sample.

Benzo(g,h,i)perylene has 6 benzene rings. Figure 9 shows the changes in the concentration of benzo(g,h,i)perylene depending on the dose of calcium peroxide Removal efficiency of benzo(g,h,i)perylene was $97 \%$ and occurred after adding $3 \mathrm{~g} / \mathrm{L}$ of $\mathrm{CaO}_{2}$. As shown the highest removal efficiency of all tested hydrocarbons was for $3 \mathrm{~g} / \mathrm{L}$ calcium peroxide. 


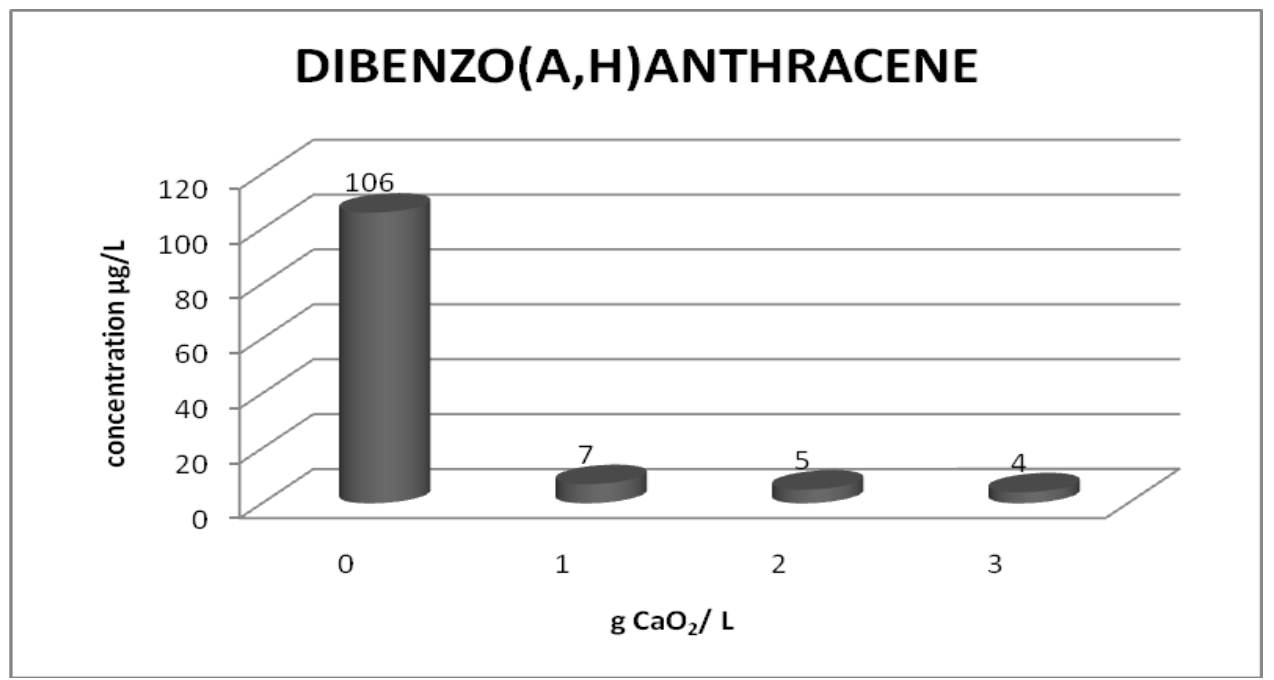

Fig. 8. Changes in the concentration of dibenzo(a,h)anthracene depending on dose of $\mathrm{CaO}_{2}$ added to sample.

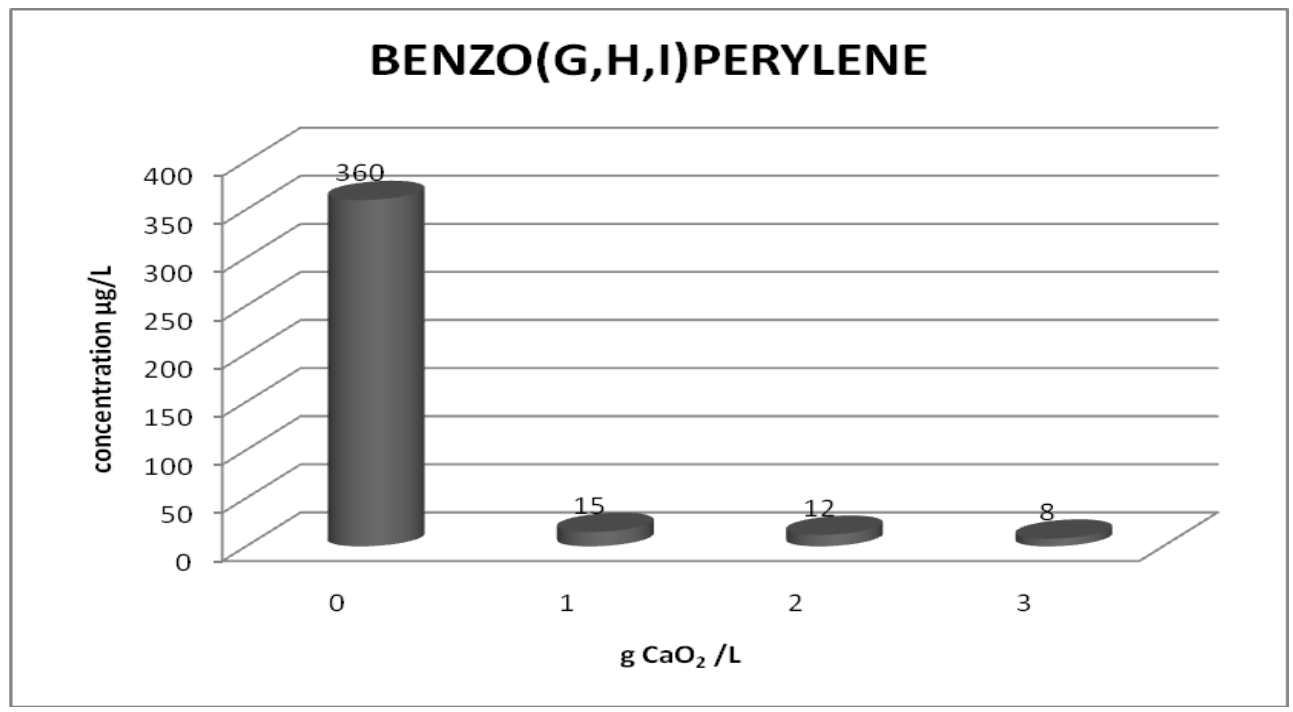

Fig. 9. Changes in the concentration of benzo(g,h,i)perylene depending on dose of $\mathrm{CaO}_{2}$ added to sample

Effectiveness of decrease the concentration pyrene was $96 \%$. It has four benzene rings in which there are 8 delocalized $\pi$ bonds. For both hydrocarbons with 4, 5 and 6 benzene rings the removal efficiency was similar and was $96-98 \%$. This suggests that the amount of rings had no effect on the oxidation efficiency. Only in case benzo(a)anthracene removal efficiency was smaller. Benzo(a)anthracene has 4 benzene rings like pyrene but its benzene rings are connected in a different way. This can cause more difficult oxidation.

\section{Conclusion}

Based on the results, the following conclusions can be drawn.

1. Removal of organic compounds expressed by COD were the range of $30-35 \%$. 
2. The effectiveness of PAH degradation was directly proportional to the calcium peroxide dose

3. The efficiency in the removal of 4-ring of PAHs were as follows : pyrene $93 \%-96 \%$, benzo(a)anthracene $89-94 \%$, chrysene 93-97\%, benzo(b)fluoranthene 96-98\%, benzo(k)fluoranthene $96-98 \%$. Removal efficiency was $97 \%$.

4. The efficiency in the removal of 5-ring of PAHs were as follows benzo(a)pyrene 9798\%, dibenzo(a,h)anthracene 95-98\%, indeno(1,2,3-cpyrene 96-98\%. After oxidaton process total concentration of 5-ring hydrocarbons was $98 \%$ lower than initial concentration.

5. The efficiency in the removal of benzo(g,h,i)perylene, were in the range of $96-98 \%$.

6. The results of the studies shown that $\mathrm{CaO}_{2}$ can be applied as a source of hydroxyl radicals to the degradation of organic pollutants, such as PAHs being present in coking wastewater.

7. Photo-Fenton process can be used for wastewater treatment highly polluted with organic pollutants such as PAHs, and primarily purified in conventional processes.

\section{References}

1. A. Kot-Wasik, D. Dąbrowska, Pub. House of Faculty of Chem Gdańsk. 700 ( in Polish) (2012)

2. F. Busetti., A. Heitz., M. Cuomo., S. Badoer , P., Traverso , J.Chromatogr., 1102, 104 115 (2006)

3. G.S. Brown, L.L Barton, B. Thomson, Waste Manag., 23, 737-740 (2003)

4. J. Wąsowski, A. Piotrowska, Environment. Protect., 85, 27-32 (2002)

5. D. Gonzalez, L.M. Ruiz, G. Garralon., F. Plaza, J. Arevalo, J. Parada et al., Desalin Water Treat., 42, 94-9 (2012)

6. I.D. Manariotis, H.K Karapanagioti et al., Water Res, 45, 2587-94 (2011)

7. K. Ravinda, R. Sokhi van Grieken., Atmos. Environ., 42, 2895-921 (2008)

8. X. Zhao, Y. Wang, Z. Ye, A.G.L. Borthwick, J. Ni, Process Biochem., 41, s. 1475-1483 (2006)

9.E. Bartulewicz, J. Bartulewicz, J. Gałkowski, Pub. House State. Depart. Hygien., 95-109 (in Polish) (1997)

10. M Włodarczyk-Makuła, Pub. House of Częstochowa University of Tech., 126, ( in Polish) (2007)

11. M Włodarczyk-Makuła, E. Wiśniowska, A. Turek, Desalin Water Treat., 57 (3), 1262 $1272(2016)$

12. A. Dugay, C. Herrenknecht, M. Czok, F. Guyon, Pages N, J. Chromatogr., 958, 1-7 (2002)

13. K. Marttinnens, R.H. Kettuner, J.A. Rintala, Sci.Total Environ., 301, 1-3 (2003)

14. A. Rubio-Clemente, R.A. Torres-Palma, G. Panuela, Sci. Total Environ, 478, 201-225 (2014)

15. A. Northup, D.J. Cassidy, Hazard. Mater, 152, 1164-1170.(2008)

16. M. Arienzo, Chemosphere 40,331-337 (2000)

17 K. Barbusiński, Pub House Silesian University of Technology, (in Polish) (2013)

18. I. Skoczko, Annual set the Environ. Protec. 15, 1460-1473 (in Polish) (2013)

19. T. Petry, P. Schmid, C. Schlatter, Chemosphere, 32, 639-648 (1996) 